\author{
MARINA Ž. ILIĆ ${ }^{1}$ \\ ŽANA P. BOJOVIĆ ${ }^{2}$ \\ DANIJELA M. SUDZILOVSKI \\ UNIVERSITY OF KRAGUJEVAC, \\ TEACHERS' TRAINING FACULTY IN UŽICE
}

\title{
TEACHERS' FOLK PEDAGOGIES ${ }^{3}$
}

ABSTRACT. In the last few decades, a large portion of scientific literature has been dedicated to the questions of realization of teaching and its improvement. However, one question remains in the background - folk pedagogies and their influence on teaching.

The main objective of this paper is to help us get acquainted with this phenomenon that exists in the teaching practice, its significance and pedagogical implications. In the first part of the paper, we deal with definitions of folk pedagogies and related concepts and their mutual relationship, in order to analyze the similarities and differences in the meaning of the concepts in use. Starting from important determinants of teachers' folk pedagogies, we will attempt to reassess some of the proposed methods and ways to raise consciousness about teachers' folk pedagogies, methods to analyze and change them. Based on the existing knowledge on teachers' folk pedagogies, we will try to point out their significance and implications they have on education practice. Starting from the existing findings about folk pedagogies, we have separated three important implications for educational practice: a) teachers should be viewed as creators of their own coherent theories about learning and teaching; b) changing and improving one's teaching practice is a result of the teacher's willingness to reflect on his or her own folk pedagogies; and c) teachers' folk pedagogies should be seen as the starting point for teacher professional development programs.

KEY WORDS: folk pedagogies; educational practice; the pedagogical implications.

\footnotetext{
marinailic@hotmail.rs

rzjzboj@ptt.rs

3 This paper was submitted on June 4, 2016 and accepted for publication at the meeting of the Editorial Board held on September 29, 2016.
} 


\section{INTRODUCTION}

Since J.A. Comenius (Коменски, 1997) established didactics as the art of teaching, didacticists are engaged in continuous efforts to answer the following questions: what is teaching and how do we teach? In the last few decades, a large portion of scientific literature has been dedicated to the questions of realization of teaching and its improvement. The literature discussed the selection and efficacy of teaching strategies, selection and efficacy of teaching methods, education systems, curricula (Baer, 2003; Baliya, 2013; Jbeili, 2012; Klimovienë \& Statkevièienë, 2006; Mitrović, 2011; Мишчевић-Кадијевић, 2011; Stevens \& Slavin, 1995a, 1995b; Woolfolk-Hoy, 2005) and other aspects of teaching. However, one question remains in the background - teachers' folk pedagogies and their influence on teaching.

The main objective of this paper is to help us get acquainted with this phenomenon that exists in the teaching practice, its significance and pedagogical implications. In the first part of the paper, we deal with definitions of folk pedagogies and related terms in order to analyze the similarities and differences in the meaning of the concepts in use. Starting from important determinants of teachers' folk pedagogies, we will attempt to reassess some of the proposed methods and ways to raise consciousness about teachers' folk pedagogies, methods to analyze and change them. Based on the existing knowledge on teachers' folk pedagogies, we will try to point out their pedagogical implications.

\section{FOLK PEDAGOGIES AND FOLK PSYCHOLOGIES - DEFINITIONS AND MEANINGS}

The discussion on the conceptual and terminological definition of folk pedagogy and related terms is important for several reasons. First, clear conceptualization of folk pedagogies is important so we could better understand their importance for the teaching practice. Second, analyzing similarities and differences in the meaning of the term ensures a chance to single out important determinants of folk pedagogies and to reevaluate the validity of using different terms: folk pedagogy, folk psychology, folk theories, theories of 
mind, implicit theories, implicit beliefs, lay beliefs. Most authors use the terms folk pedagogy and folk psychology, so we will begin with them.

Olson \& Bruner (1996) define folk psychologies as intuitive, everyday, layperson, often implicit theories on the human mind which direct the actions and behaviors of people. In addition to this, folk psychologies are biologically and culturally based beliefs about the human mind (Bruner, 2000; Olson \& Bruner, 1996). In their definition, Olson and Bruner (1996 $\left.{ }^{a}\right)$ point out to the characteristics of folk psychologies on the one hand, and to their origin and sources on the other. Namely, we have these theories that are not a result of rational cognition, they are inherent, implicit, not always expressed with words, and of different origin.

Strauss (2001) defines folk psychologies as ways in which laypersons represent the nature of the psychological world of people, meaning primarily beliefs about the human mind and learning. Strauss emphasizes that those are intuitive and implicit beliefs of laypersons who did not study the human psyche and related fields of psychology.

Wellman and Lagattuta (2004) use the terms theories of mind and folk psychology as synonyms. According to these authors, folk psychologies represent "our everyday understanding of persons in terms of their inner psychological states" (Wellman and Lagattuta, 2004, p. 479). These authors do not associate folk psychologies exclusively with cognition, but move the focus toward other psychological states of people, their beliefs, wishes, intentions, emotions.

Olson and Bruner (1996)a define folk pedagogies as intuitive, everyday, often implicit theories on teaching.

"Watch any mother, even a baby-sitter with a child, and you will be struck at how much of what they do is guided by notions of what children's cognitive abilities are like and how one may help them learn, even though they may not be able to verbalize their pedagogical principles" (Bruner, 2000, p. 58).

In situations when the teacher teaches, when we help children do their homework, or study, our hidden beliefs on the children's mind are revealed. This is why Bruner believe that folk pedagogies are a reflection of folk psychologies, in other words, teachers' beliefs and assumptions about the minds of students. On the other hand, teachers' folk pedagogies reflect their cultural beliefs on teaching and learning. Thus, teachers' folk pedagogies also reflect 
the dominant folk culture of the specific school and town they work in. The tacit knowledge of a certain culture will be integrated in teachers' personal folk pedagogies.

Antić (2007) uses the terms implicit theories, lay beliefs, folk psychology and folk pedagogy. These synonyms "refer to explicit and non-explicit knowledge, beliefs, attitudes, which can be of different origins (from personal, familial, cultural or general human experience), but possessed by each individual" (Antić, 2007, p. 50-51).

Pešikan (2010) uses the terms implicit theories and folk theories, meaning "everyday intuitive theories about how other people think, especially how children learn and what their success (folk psychology) depends on, and theories on how to help children learn (folk pedagogy)" (p. 176). They are personal, private, often unconscious theories, which are hard to verbalize and use as a basis for discussion, but which nonetheless affect our actions and behaviors.

Suzić (1997) uses the terms implicit theories and implicit beliefs and offers the following definition:

"They are preconceptions and prejudices teachers and students have about teaching and learning. They are actually stereotypes and values, which normally act subconsciously" ( $p$. 408).

Torff (1999) and Antić (2007) a suggest the need to distinguish between folk pedagogy and folk psychology on the one hand, and groups of terms that denote intuitive and naive understanding of subject-matter from various fields on the other. Both groups of terms signify partly personal, partly collective beliefs about the world around us (Антић, 2007), they are manifested in various situations, they are often hidden, in the form of assumptions, they represent simplified notions and exhibit a tendency to survive (Torff, 1999). The key difference between these terms is in their subject-matter, i.e. the area in which they manifest (Антић, 2007; Torff, 1999). Naive theories of children and adults are associated with the phenomena from the natural and social reality, which are parts of the curriculum, whereas folk pedagogy is associated with education and teaching (Антић, 2007; Torff, 1999). Another key difference between these two groups of terms is the existence of an organized and institutionalized activity against the naive theories about nature and society. Namely, "every culture embodied in the 
school system actively works on opposing students' private beliefs about the world around them and on establishing a system of coherent and systematized scientific knowledge in place of these personal beliefs" (Антић, 2007, p. 51). Indeed, there is no such organized and institutionalized activity that works against teachers' folk pedagogies with the objective of establishing a single coherent teachers' theory about teaching and learning. There are attempts to introduce future teachers to the importance of teachers' folk pedagogies during their formal education, to face them with their folk pedagogies during practical classes in schools, as well as attempts of teachers to change folk pedagogies that shape their teaching practice and raise their consciousness regarding them. However, the strength and presence of these attempts, although mostly foreign experiences, cannot even come close to the campaign led against the naive children theories about the content of the curriculum. It is justified to ask - Is the campaign against naive and intuitive children theories a result of unconscious folk pedagogies educational practice is based on? Why is there no such campaign against folk pedagogies of teachers, if they are also intuitive and naive beliefs about teaching and learning? It appears that in actual educational practice, there are attempts to change intuitive beliefs of one group on behalf of another group. It appears we are more bothered by the intuitive belief about pressure, than the intuitive belief about teaching and learning.

The previous review indicates that the choice of the term implicates the author's attitude toward such an important phenomenon. We will take another look at terms some authors use as synonyms to consider the adequacy of their use. The term "lay belief " does not include all that folk pedagogies represent, because it insists only on one of their determinants, although an important one. In addition, there is no clear difference between lay beliefs that occur in various fields: physics, biology, psychology (Антић, 2007). The term »implicit theories" emphasizes that the theories in question are teachers' theories that can be verbalized with difficulty. Some authors speak about folk pedagogies as personal theories. This is acceptable in the sense that everyone has a personal folk pedagogy. Different folk pedagogies of laypersons and teachers originate from their different assumptions about the child's mind, teaching and learning (Olson \& Bruner, 1996). Folk pedagogies of teachers are personal theories, beliefs and assumptions, but first they had to be a social relationship, whether between two persons, or between an 
individual and a culture he or she belongs to. So, there is a justified need to question the use of certain terms, such as "implicit beliefs" and »lay beliefs «, due to insufficient distinction from related terms, present in various areas of natural and social reality.

An insight into current conceptualizations of the term folk pedagogy points out to the following six overlapping features and important determinants: a) they have a unique content; b) they occur in the form of implicit and tacit knowledge; c) they represent stable intuitive beliefs that resist change; d) they are characteristic of all people (children and adults, lapersons and professionals); e) they have a direct impact on the teaching practice (behavior, actions, choice of teaching strategies, interactions, student and teacher activities); f) they are subject to reflection and change; and g) they have various origin and sources (as cited in: Илић и Бојовић, 2015).

First, many authors (Antić, 2007; Bruner, 2000; Olson \& Bruner, 1996; Pešikan, 2010; Suzić, 1997; Torff, 1999) agree that folk pedagogies represents beliefs and assumptions about teaching and learning .

Second, numerous authors underline that folk pedagogies have a form of implicit and tacit knowledge. Namely, during activities in the teaching practice we are often unable to find appropriate words to describe the way we teach others and help them learn. For this reason, we say such knowledge in our actions is hidden and tacit.

The third important determinant of teachers' folk pedagogies indicates that they are stable beliefs about teaching, resistant to change. Despite teacher professional development programs and teaching experience, teachers' folk pedagogies tend to remain unchanged, even in circumstances when the teacher shows initiative to improve his or her teaching practice.

Authors agree that folk pedagogies and folk psychologies are characteristic of all people (children and adults, laypersons and professionals), which represents their fourth determinant. Laypersons, who were not prepared for the teaching profession through their initial education also have their beliefs about the mind, teaching and learning. Strauss (2001) ${ }^{\mathrm{a}}$ believed in the difference between folk psychologies of laypersons and folk psychologies of cognitive psychologists. He abandoned the assumption about the difference between folk psychologies of laypersons and scientists during a meeting dedicated to establishing the Center for Research on Teaching and Learning in Tel Aviv. In that meeting, scientists from 
different fields presented their models of learning. Despite the differences among them regarding their models of choice, Strauss noticed a common characteristic. Namely, all of them taught in the same way, that the cause of learning is in another, in other words, they had the same folk psychologies about the mind and learning. That folk theories are also characteristic of children was confirmed by the study conducted by Tikva (Tikva, 2010). It was proved students support the folk belief that teaching occurs only when there is a direct transmission of knoweldge, and explanations and demonstrations as teaching strategies occur independently of the teacher's intention to teach and whether their actions cause learning in their students or not.

The fifth important determinant refers to the viewpoint that folk pedagogies have a direct influence on teachers' actions, behavior and practice. It points out that teachers' assumptions on the child's mind, learning and teaching form the teaching practice, whether the teacher is aware of the fact, or not.

The sixth overlapping feature of teachers' folk pedagogies is the possibility of raising one's consciousness regarding them, reassessing and changing them, despite their tendency to survive and remain unchanged. Authors agree that there is a need to raise one's consciousness about folk pedagogical beliefs and to explicate them, although they suggest different methods of changing them.

\section{POTENTIAL WAYS TO RAISE ONE'S CONSCIOUSNESS ABOUT TEACHERS' FOLK PEDAGOGIES, TO QUESTION AND CHANGE THEM}

On the premise that teachers' folk pedagogies are important for improving current educational practice this chapter examines ways to raise consciousness about teachers' folk pedagogies, to question and change them. In foreign scientific literature, we can single out the ideas of Torff (1999), Minstrell (1999) and Barrett (1997). The first initiatives in our scientific literature come from authors such as Pešić (1998a, 1998b), Marinković (2011) and Pešikan (2010). Given that we have recognized the potential for changing teachers' folk pedagogies in them, we decided to present them first, and then analyze them from the aspect of possibilities they offer to teachers to change their folk pedagogical beliefs. 
In the contex of initial teacher education program, Torff (1999) suggested three steps that should be taken in order to encourage teachers to engage in the reflection about folk pedagogies: a) facing teachers with folk pedagogies and raising their consciousness about the nature and omnipresence of folk pedagogies; $b$ ) encouraging teachers to use alternative models of teaching in order to perceive their advantages, and c) helping teachers to develop different teaching styles that correspond to the aims of the curriculum. Within the first step, teachers should be enabled to face and critically evaluate their folk pedagogies as the foundation on which their decisions in the classroom are made. The second step suggested by Torff starts from the requirement that teachers should become aware of the need to focus on the thoughs and intentions of their students. The final step involves the creation of classroom activities that encourage future teachers to analyze the aims of the curriculum and ways to realize them (e.g. choice of teaching methods in relation to the established objectives and content).

Minstrell (1999) a did not develop steps for raising consciousness about teachers' folk pedagogies. His view of his own teaching practice represents a special kind of reflection on the teaching practice in an attempt to build a coherent theory about teaching and learning. This author proposed three steps necessary for the development of professional expertise: a) observation and reflection on one's own teaching experience; b) relationship with one's mentor, and c) active participation/involvement in professional networks. In that gap between what he achieved and what he want$e d$, he started researching other approaches to teaching with the intention of discovering an approach that respects students' attitudes most and encourages learning. On the way to developing his personal coherent view on teaching and learning, Minstrell had the support of his mentor. As he observed him showing students what to do, the mentor told him: "Keep your hands in your pockets and the students will show you how they would answer the question" (Minstrell, 1999, p. 227). When he would see what Minstrell was telling his students to do, or how to think, he would tell him: "You have two ears and one mouth, use them in that proportion" (Minstrell, 1999, p. 227). In addition to his mentor, Minstrell also had the support of other physics teachers, because he actively participated in professional networks for physicists. With his reflection on teaching, Minstrell demonstrates that, in order to change and improve one's practice, one needs to continuously 
monitor and observe it, so as to comprehend it better, and one also needs others who will support him and represent a kind of mirror for what he really does, without being sufficiently aware of it.

Barrett (1997) a explored his own folk pedagogies simultaneously with the moral dimensions of folk pedagogies of university professors. Barrett's work suggests the following key moments: a) awareness about the flaws of one's own practice encourages reflection and the need to change one's folk pedagogies; $b$ ) narratives are an important form of recognizing one's own folk pedagogies; and c) studying folk pedagogies of others contributes to a better uderstanding of one's own folk pedagogies. A feeling of dissatisfaction stemming from the teaching practice motivated Barrett to reflect on his own teaching practice. Narratives represented the best way for him to present his teaching experiences and his own conceptions of teaching and learning. Studying university professors' implicit folk beliefs, based on their narratives about teaching and learning, and observing their actual practice enabled Barrett to review and reflect once again on his personal folk beliefs about teaching. His entire body of work is permeated with a discourse on the essence of education and the transformation of the attitude that teaching is "teaching subjects" into the attitude that teaching is "teaching people" (Barrett, 1997, p. v). He argues the attitude that teaching is a moral act rather than transferring content to students with the following words:

"Because it involves making decisions and taking actions on behalf of others, it is inherently moral. Because it involves helping people to develop a particular view of the world, it is inherently moral" (Barrett, 1997, p. v).

Pešikan (2010) ${ }^{\mathrm{a}}$ and Marinković (2011) ${ }^{\mathrm{a}}$ indicate the need to raise consciousness and explicate implicit teachers' theories, by comparing them with the existing official theories about teaching and learning, both during initial teacher education and during further professional development.

According Pešić (1998a) $)^{a}$, action research has a significant role in raising the awareness and changing folk beliefs of teachers, because it is "simultaneously an action and a research, a process of changing the practice and the construction of knowledge" (Pešić, 1998a, p. 23).

Presented ideas can be largely promising for developing steps and taking specific measures toward changing teachers' folk peda- 
gogies. Bearing in mind the displayed ways to change folk pedagogies, we particularly recommend the following steps: a) the initiative has to come from the teacher; b) the existence of adequate support in comprehending the practice derived from folk pedagogies; and c) reflection on one's personal folk pedagogies is essential in order to change them. To raise consciousness about folk pedagogies, we need some perceived noncorrespondence the teacher himself arrived at. Another key issue refers to the existence of adequate support of other direct participants in educational work (colleagues). Their role is reflected in the fact that various feedback mirrors what the teacher actually does in practice. After that, their mutual discussion and analysis of what they saw happening in actual teching practice are useful. Therefore, learning about a practice that has both an implicit and an intuitive basis includes both one's own interpretations and the interpretations of others. An insight into the intentions and actual actions of others requires a discourse between all participants in a specific social situation (Pešić, 1998a). In consequence, a key role in the process of changing teachers' folk pedagogies belongs to reflection. Through the process of reflection, we reevaluate beliefs implicit in teachers' actions. After that, teachers can arrive at a different theory about teaching and learning, created in a practice they can reassess. From the aspect of teachers' folk pedagogies, it is important to be consciousness of them and learn which folk pedagogies shape the teaching practice, what situations are favorable for the preservation of folk pedagogies, in other words, are there any other elements within the school context that obstruct the processes of raising consciousness about folk pedagogies and changing them.

\section{PEDAGOGICAL IMPLICATIONS OF TEACHERS' FOLK PEDAGOGIES}

Folk pedagogies have a multiple importance, which can be analyzed from different perspectives: from the aspect of culture, teachers, scientists and researchers, educational policy makers.

From the teacher's perspective, which is the focus of this paper, folk pedagogies are a foundation for the development of coherent teachers' theories about education and teaching. Educational prac- 
tice is based on a set of folk pedagogical and psychological beliefs of its direct participants, some of which may contribute to, and some of which may damage student development (Bruner, 2000; Olson \& Bruner, 1996). Bruner (1996)? emphasizes that the choice of the pedagogical model always contains an implicit message about the student's mind. Thus, the didactic teaching is based on the teachers' belief that students are empty vessels that should be filled with knowledge, and imitation on the assumption that students lack the skills that can be developed by imitating a model. If choices and decision making in the classroom are based on teachers' implicit and intuitive beliefs about students, teaching and learning, then the process of making these implicit beliefs conscious and exploring them would provide an insight into the actual practice derived from the appropriate folk pedagogy and folk psychology. Only on the basis of those findings would it be possible to build one's own coherent theory of learning and teaching, simultaneously questioning if it is focused on student wellbeing.

From the most recent findings about teachers' folk pedagogies, we can derive the following implications: a) teachers should be viewed as creators of their own coherent theories about learning and teaching; $b$ ) changing and improving one's teaching practice is a result of one's willingness to reflect on his or her folk pedagogies; c) teachers' folk pedagogies should be analyzed as the starting point for the teacher professional development programs.

The derived implications point out to the need for creating a new view of teachers and their competences. According to the previously dominant paradigm, the teacher was seen almost exclusively as a practitioner, who was expected to implement the knowledge of explicit (formal) theories (Pešić, 1998b). Unfortunately, the fact is that teachers in our country learn almost nothing about teachers' folk pedagogies, their significance and implications for teaching and learning during in-service training programs. If in-service teacher programs were to be based on the findings about folk pedagogies, they would involve major changes in the organization of professional practice at schools. There are two problems at the root of this information. Can educators in-service teacher programs encourage teachers to change their folk pedagogical beliefs, and if they can, to what extent? Teaching and learning are too complex to be predefined, ignoring the context of their implementation. Teachers are often unaware of their folk pedagogies, because they are in the form of tacit and implicit knowledge. Decisions and 
actions in teaching often assume knowledge that can become accessible only through practice (Bruner, 2000). Another problem occurs when teachers' unconscious folk pedagogies begin interfering with formal theories they adopted during initial education and in-service training (Torff, 1999). Then we have a gap between what teachers think they do, and what they actually do in practice (Pešić, 1998b). For these reasons, teachers principally need support to identify and solve practical problems stemming from their folk pedagogies. At any rate, the change cannot be solved outside the school, and then implemented in it. Changing teachers' folk beliefs does not imply a change of explicit (formal) theories, but a change of implicit theories their teaching practice is based on, and understanding their relationship toward the official theories.

CONCLUDING REMARKS

Three central themes are addressed: a) definition and meaning of teachers' folk pedagogies and related terms; b) ways to raise consciousness about teachers' folk pedagogies, to question and change them; and c) pedagogical implication of teachers' folk pedagogies.

There is no universally accepted definition of teachers' folk pedagogies. An insight into the existing conceptualization of the term folk pedagogy indicates the following overlapping features: they have a unique content, they manifest in the form of implicit and tacit knowledge, they represent fairly stable beliefs resistant to changes, they are imminent to all people, they directly affect teaching practice and they are subject to reflection and change.

Raising consciousness about teachers' folk pedagogies, reviewing and changing them is not an easy process. There are different opinions regarding the methods of raising consciousness about folk pedagogies and methods of changing them. Barrett, Minstrell and Torff gave promising initiatives in that sense. Keeping in mind important determinants of folk pedagogies, we believe action research provides most opportunities for teachers to become aware of their folk beliefs and change them.

Folk pedagogies are not a phenomenon that is good or bad in itself. Although folk pedagogies often prevent teachers from acting in the best interest of the overall student development, they still have a multiple importance and implications for educational practice. Starting from the existing findings about folk pedagogies, we 
have separated three most important implications for educational practice: a) teachers should be viewed as creators of their own coherent theories about learning and teaching; b) changing and improving one's teaching practice is a result of the teacher's willingness to reflect on his or her own folk pedagogies, and perceive the relationship between their practice and the formal theories about learning and teaching on the basis of that "conscious knowledge"; and c) teachers' folk pedagogies should be seen as the starting point for the teacher professional development programs.

REFERENCES Антић, C. (2007). Заблуде у знању које остају упркос школском учењу.

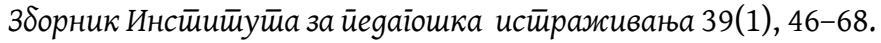

Baer, J. (2003). Grouping and achievement in cooperative learning. College teaching 51(4), 169-174.

Baliya, R. (2013). Enhancing Writing Abilities of Primary Class Students Throught Cooperative Learning Strategies: An Experimental study. International Journal of Behavioral Social and Movement Sciences 2(1), 294-305.

Barrett, T. S. (1997). Exploring the Moral Dimension of Professors Folk Pedagogy (Doctoral dissertation). Blacksburg, Virginia: Faculty of the Virginia Polytechnic Institute and State University.

Bruner, Dž. (2000). Kultura obrazovanja. Zagreb: Eduka.

Jbeili, I. (2012). The Effect of Cooperative Learning with Metacognitive Scaffolding on Mathematics Conceptual Understanding and Procedural Fluency. International Journal for Research in Education (IJRE) 32, 45-70.

Klimovienë, G. \& Statkevièienë, S. (2006). Using Cooperative Learning to Develop Language Competence and Social Skills. Studies About Languages, 8 , 77-83.

Коменски, J. А. (1997). Велика gияакӣuка. Београд: Завод за уџбенике и наставна средства.

Marinković, S. (2011). Koncepcija aktivnog učenja kao osnova za formiranje novih nastavničkih kompetencija. Pedagogija 66(2), 204-214.

Маринковић, С. (2013). Виђење детета и детињства из угла народне педагогије. 3ठорник раgова 15, 23-36.

Minstrell, J. (1999). Expertise in Teaching. In: R. J. Sternberg \& J. A. Horvath (Eds.), Tacit Knowledge in Professional Practice: Researcher and Practitioner Perspectives (pp. 215-230). Mahwah, NJ: Lawrence Erlbaum Associates Inc.

Mitrović, M. (2011). O novim konceptima metoda u nastavi. Pedagogija 66(1), 168-172. 


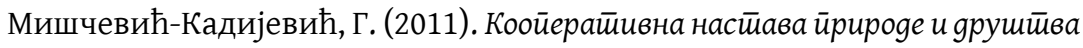

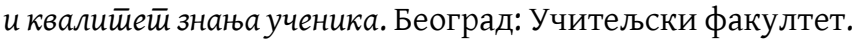

Olson, D. R., \& Bruner, J. S. (1996). Folk psychology and folk pedagogy. In: D. R. Olson \& N. Torrance (Eds.), The Handbook of education and human development: New models of learning, teaching and schooling (pp. 9-27). Cambridge: MA: Blackwell.

Pešikan, A. (2010). Savremeni pogled na prirodu školskog učenja i nastave: Socio-konstruktivističko gledište i njegove praktične implikacije. Psihološka istraživanja 12(2), 157-184.

Pešić, M. (1998a). Akciono istraživanje i kritička teorija vaspitanja. U: Pešić i sar., (prir.), Pedagogija u akciji: metodološki priručnik (str.19-30). Beograd: Institut za pedagogiju i andragogiju Filozofski fakultet.

Pešić, M. (1998b). Istraživanje praktičara. U: Pešić i sar., (prir.), Pedagogija u akciji: metodološki priručnik (str. 59-74). Beograd: Institut za pedagogiju i andragogiju Filozofski fakultet.

Stevens, R. J. \& Slavin, R. E. (1995a). Effects of a Cooperative Learning Approach in Reading and Writing on Academically Handicapped and Nonhandicapped Students. The Elementary School Journal 95(3), 241-262.

Stevens, R. J. \& Slavin, R. E. (1995b).The Cooperative Elementary School: Effects on Students Achievement, Attitudes and Social Relations. American Educational Research Journal 32 (2), 321-351.

Strauss, S. (2001). Folk Psychology, Folk pedagogy and Their Relations to Subject Matter Knowledge. In: B. Torff \& R. J. Sternberg (Eds.), Understanding and Teaching the Intuitive Mind (pp. 217-242). Mahwah, NJ: Erbaum.

Сузић, Н. (1997). Имплицитне теорије о настави и учењу. Насӣава и учење 46(4), 408-427.

Tikva, J. B. (2010). Socratic teaching is not teaching, but direct transmission is: Notes from 13 to 15-olds conceptions teaching. Teaching and Teacher Education 26, 656-664.

Torff, B. (1999). Tacit Knowledge in Teaching: Folk Pedagogy and Teacher Education. In: R. J. Sternberg, \& J. A. Horvath (Eds.), Tacit Knowledge in Professional Practice: Researcher and Practitioner Perspectives (pp. 195-214). Mahwah, NJ: Lawrence Erlbaum Associates Inc.

Wellman, H. M. \& Lagattuta, K. H. (2004). Theory of mind for learning and teaching; The nature and role of explanation. Cognitive Development 19, 479-497.

Woolfolk-Hoy, A. E. (2005). Active learning. Boston: Allyn \& Bacon. 
МАРИНА Ж. ИЛИЋ

ЖАНА П. БОЈОВИЋ

ДАНИЈЕЛА М. СУДЗИЛОВСКИ

УНИВЕРЗИТЕТ У КРАГУЈЕВЦУ,

УЧИТЕљСКИ ФАКУЛТЕТ У УЖИЦУ

РЕЗИМЕ

ФОЛК ПЕДАГОГИЈА У НАСТАВИ

У последњим деценијама велики део научне литературе је посвећен питањима реализације и унапређивања наставе. Расправљало се и писало о избору и ефикасности наставних стратегија, избору и разноврсности наставних метода, наставним системима, наставним програмима, и осталим аспектима наставе. Ипак, једно питање остаје занемарено и у другом плану - фолк педагогије и њихов утицај на наставу.

Основни циљ рада је да се упознамо са овим феноменом присутним у образовној пракси, његовим значајем и педагошким импликацијама. У првом делу рада бавимо се одређењем фолк педагогија и сродних појмова, њиховим међусобним односом са циљем разматрања сличности и разлика у садржају појмова који су у употреби. Анализом најзаступљенијих дефиниција издвојене су суштинске одреднице фолк педагогија: имају особен садржај (наставу и подучавање), испољавају се у форми имплицитног знања, представљају прилично стабилна уверења, инхерентно су својство свих људи, директно утичу на наставну праксу и подложне су рефлексији и мењању.

У литератури се издвајају различити начини освешћивања, преиспитивања и мењања фолк педагогија наставника. Са становишта непосредне образовне праксе и рада наставника посебно се издвајају три корака у процесу разумевања и мењања фолк педагогија: а) мењање фолк педагогија покреће наставник увидом у раскорак и противречности властите наставне праксе; $\delta$ ) у сазнавању праксе проистекле из фолк педагогија потребна је адекватна подршка других; и в) рефлексија над сопственим фолк педагогијама је нужна за процес њиховог освешћивања.

Полазећи од постојећих сазнања о фолк педагогијама издвојили смо три важне педагошке импликације: а) наставнике треба посматрати као ствараоце сопствених кохерентних теорија о настави и учењу; $\delta$ ) мењање и унапређивање наставне праксе је резултат спремности наставника да рефлектују над сопственим фолк педагогијама; и ц) фолк педагогије наставника 
треба разматрати као полазиште за професионални развој наставника.

Кључне речи: фолк педагогије; образовна пракса; педагошке импликације; програми иницијалног образовања наставника. 